\title{
PENGARUH KONDISI LINGKUNGAN TERHADAP KERAWANAN KEJAHATAN DI KAWASAN PERKOTAAN Studi Kasus di Kecamatan Sumur Bandung, Kota Bandung
}

\author{
Moh. Dede ${ }^{1}$, Dede Sugandi' ${ }^{2}$, Iwan Setiawan ${ }^{3}$ \\ ${ }^{1}$ Departemen Pendidikan Geografi, Universitas Pendidikan Indonesia \\ ${ }^{2}$ Departemen Pendidikan Geografi, Universitas Pendidikan Indonesia \\ ${ }^{3}$ Departemen Pendidikan Geografi, Universitas Pendidikan Indonesia \\ E-Mail: desa96@student.upi.edu
}

\section{RINGKASAN}

Kota Bandung merupakan salah satu kota dengan tingkat kejahatan tertinggi di Indonesia dan Asia Tenggara (Erizal, 2017). Setiap tahunnya Kota Bandung berkontribusi atas 16 hingga 20 persen crime total di Jawa Barat. Kota Bandung memiliki tingkat kerawanan kejahatan mencapai 65 persen dengan aglomerasi kejahatan berada di wilayah barat dan pusat kota (Dede, Setiawan, \& Mulyadi, 2017). Salah satu wilayah di kota ini yang memiliki tingkat kejahatan tertinggi adalah Kecamatan Sumur Bandung. Pada tahun 2017, Sumur Bandung memiliki crime total mencapai 341 kasus dan crime rate mencapai 190,77 (Polrestabes Bandung, 2017). Sebagai fenomena spasial, kejahatan senantiasa memiliki pola sebaran tertentu serta terikat dengan berbagai kondisi lingkungan (faktor eksternal) seperti kependudukkan, ekonomi, morfologi perkotaan, dan intervensi sosial (Matthews, 2013).

Penelitian ini bertujuan untuk mengetahui pengaruh spasial kondisi lingkungan terhadap kerawanan kejahatan di Kecamatan Sumur Bandung. Kondisi lingkungan terbagi atas variabel batas antar ruang privat, aksesibilitas, jumlah penduduk, kondisi ekonomi, dan iklim sosial. Penelitian ini berbasis pada penelitian survei dengan menggunakan 176 responden dan margin of error sebesar 3,5 persen yang dipilih secara multistage random sampling pada 37 rukun warga di Kecamatan Sumur Bandung. Dengan pendekatan kuantitatif, data kejahatan dianalisis secara geostatistik menggunakan teknik kernel density estimation (KDE) guna menghasilkan informasi kerawanan kejahatan esksiting. Informasi kerawanan kejahatan hasil KDE divalidasi menggunakan mean error (ME), root mean square error (RMSE), dan $r^{2}$. Hubungan antar variabel dianalisis menggunakan multiple linear regression dan partial correlation yang sebelumnya telah melaui serangkaian uji asumsi klasik seperti uji normalitas, uji linearitas, uji heteroskedastisitas, dan uji autokorelasi. Secara spasial, pengaruh antara variabel kondisi lingkungan dan kerawanan kejahatan eksisting secara lokal di Kecamatan Sumur Bandung dianalisis menggunakan geographically weighted regression (GWR).

Hasil luaran KDE yang telah divalidasi menunjukkan bahwa kerawanan kejahatan eksisting Kecamatan Sumur Bandung memiliki kecenderungan memusat pada bagian barat wilayah ini, tepatnya di Kelurahan Braga dan Kelurahan Babakan Ciamis. Hasil analisis multiple linear regression menunjukkan seluruh variabel kondisi lingkungan memiliki pengaruh secara simultan terhadap kerawanan kejahatan eksisting secara signifikan. Tingkat determinasi kondisi lingkungan terhadap kerawanan kejahatan eksisting mencapai 65,7 persen dengan tingkat kepercayaan mencapai 99 persen, hal ini menunjukkan bahwa kejadian kejahatan di Kecamatan Sumur Bandung lebih dominan dipengaruhi oleh faktor eksternal yang berperan sebagai crime generator. Secara parsial, hanya variabel iklim sosial yang tidak memiliki pengaruh signifikan terhadap kerawanan kejahatan eksisting. Fenomena ini dapat diartikan bahwa iklim sosial masyarakat di Kecamatan Sumur Bandung relatif serupa, baik pada wilayah yang rawan kejahatan maupun sebaliknya. Sementara itu, aksesibilitas merupakan variabel yang memiliki pengaruh tertinggi secara positif terhadap kerawanan kejahatan eksisting, hal ini berarti wilayah dengan tingkat aksesibilitas tinggi akan memiliki kerawanan kejahatan yang tinggi.

Kondisi berbeda terjadi pada variabel batas antar ruang privat, variabel ini memiliki kontribusi tertinggi secara negatif terhadap kerawanan kejahatan eksisting. Di Kecamatan Sumur Bandung, wilayah dengan rasio gated community yang tinggi umumnya memiliki kerawanan kejahatan yang lebih rendah. Berdasarkan hasil korelasi parsial juga ditemukan adanya hubungan antar variabel bebas yang signifikan yakni antara kondisi ekonomi dan batas antar ruang privat. Hal ini terjadi karena latar belakang ekonomi penghuni gated community biasanya lebih tinggi daripada penghuni kompleks pemukiman yang tidak berpagar, hal ini disebabkan oleh citra dan harga rumah yang dipatok di lingkungan berpagar biasanya lebih mewah dan elit. 


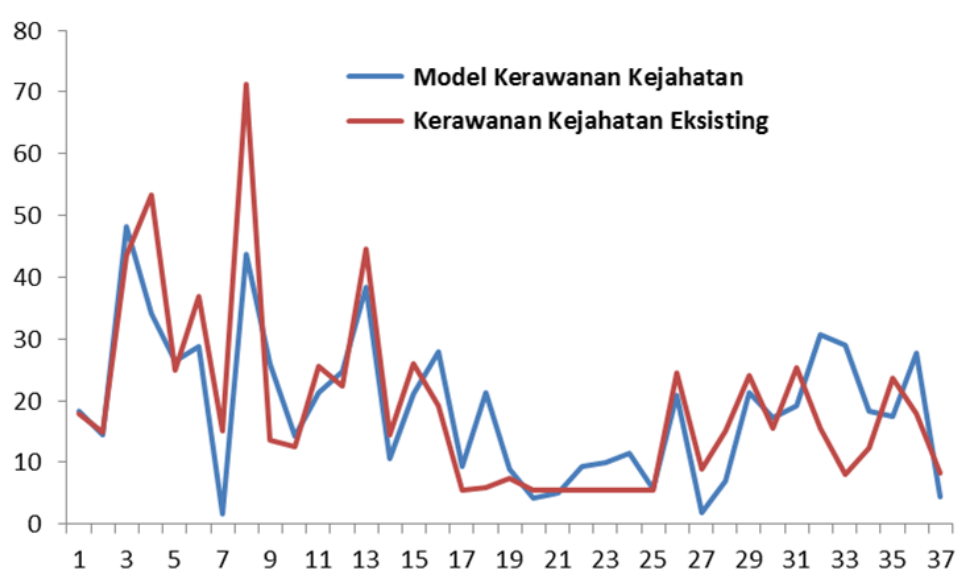

Gambar 1. Komparasi Pemodelan Kerawanan Kejahatan Berbasis Lingkungan dan Kerawanan Kejahatan Eksisting

Berdasarkan input pada persamaan regresi diketahui bahwa pemodelan kerawanan kejahatan berbasis kondisi lingkungan di Kecamatan Sumur Bandung memiliki nilai akurasi mencapai 0.78 (gambar 1). Analisis GWR menunjukkan bahwa kondisi lingkungan memiliki pengaruh yang lebih tinggi terhadap kerawanan kejahatan eksisting pada bagian utara Kelurahan Babakan Ciamis dan bagian tengah hingga selatan Kelurahan Braga (gambar 2). Kondisi lingkungan yang suitable terhadap kejahatan memiliki pola yang memusat serta memiliki penurunan dari arah barat menuju ke arah timur Kecamatan Sumur Bandung.

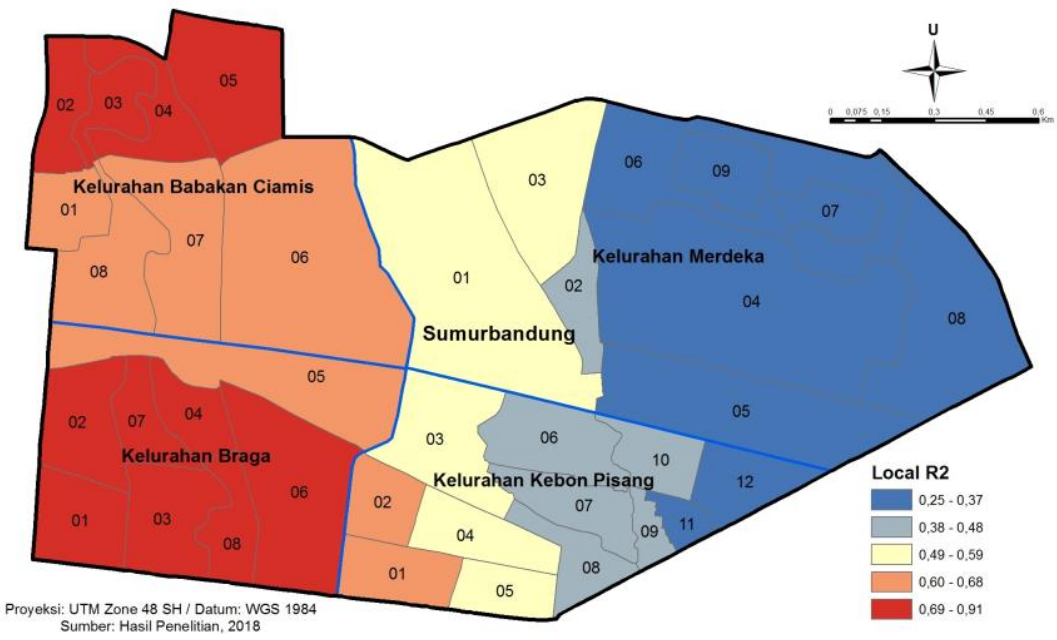

Gambar 2. Sebaran Spasial Pengaruh Kondisi Lingkungan terhadap Kerawanan Kejahatan

Hasil analisis spasial kondisi lingkungan terhadap kerawanan kejahatan di Kecamatan Sumur Bandung menunjukkan faktor eksternal memainkan yang lebih dominan dibandingkan faktor internal dalam setiap tindak kejahatan. Lingkungan dapat berperan sebagai crime generator yang menciptakan suitable target bagi para pelaku kejahatan. Oleh sebab itu, pencegahan kejahatan harus dilakukan secara terpadu dengan melibatkan aspek spasial-lingkungan baik oleh pemerintah, aparat kemananan, maupun masyarakat.

\section{UCAPAN TERIMA KASIH}

Terima kasih kepada Brigadir (Pol.) Eko Purwanto (Polrestabes Bandung) dan IPTU (Pol.) Ade (Polsek Sumur Bandung) atas kesediaan data dan waktunya. Selain itu, penulis juga ucapkan banyak terima kasih kepada penduduk Kecamatan Sumur Bandung atas kesempatan untuk terlibat dalam penelitian.

\section{DAFTAR PUSTAKA}

Erizal, E. (2017). Analisis Faktor-Faktor yang Mempengaruhi "Crime Rate" di Indonesia tahun 2011-2015 (Tesis). Fakultas Ekonomi, Universitas Andalas.

Dede, M., Setiawan, I., \& Mulyadi, A. (2017). Application GIS to Analyse Crime Risk in Bandung. The 2nd International Conference of Sociology Education (pp. 597-602). Bandung: Scitepress.

Matthews, S. (2013). Geoprofiling crime: engaging students with lessons from applied geography. Dipresentasikan pada AGTA 2013 Perth Geography's New Frontier, Perth College, Western Australia.

Polrestabes Bandung. (2017). Data Tindak Pidana Tahun 2017. Bandung: Tidak Diterbitkan. 